\title{
Pengembangan Lembar Kegiatan Siswa Berbasis Metode Penemuan Terbimbing untuK PEMbelajaran Matematika PADA SISWA KELAS XII SMA NEGERI 1 SEGERI
}

\author{
THE DEVELOMPENT OF STUDENTS' ACTIVITY SHEET BASED ON DISCOVERY LEARNING \\ FOR MATHEMATICAL LEARNING ON STUDENTS ClaSS XII SMA NEGERI 1 SEgERI
}

\author{
Zam Immawan Alam ${ }^{1}$ dan Firdha Razak ${ }^{2}$ \\ 1Pendidikan Matematika, STKIP Andi Matappa Pangkep \\ Jl. Andi Mauraga No 70, Kabupaten Pangkajene Kepulauan, Sulawesi Selatan, Indonesia \\ 2Pendidikan Matematika, STKIP Andi Matappa Pangkep \\ Jl. Andi Mauraga No 70, Kabupaten Pangkajene Kepulauan, Sulawesi Selatan, Indonesia \\ firdarazak@yahoo.com
}

\begin{abstract}
Abstrak
Penelitian ini adalah penelitian pengembangan (Research and Development) dengan uji coba terbatas yang bertujuan untuk mengembangkan lembar kegiatan siswa matematika berbasis metode penemuan terbimbing. Subjek penelitian ini adalah siswa kelas XII IPS 3 SMA Negeri 1 Segeri dengan jumlah siswa sebanyak 27 orang. Prosedur pengembangan yang digunakan dalam penelitian ini adalah model ADDIE yang meliputi lima tahap, yaitu tahap analisis, tahap desain, tahap pengembangan, dan tahap implementasi dan evaluasi. Lembar Kegiatan Siswa yang dikembangkan dengan metode penemuan terbimbing divalidasi dan mengalami beberapa kali revisi sehingga didapatkan hasil yang layak untuk digunakan. Hasil dari uji coba terbatas menunjukkan bahwa (1) skor rata-rata yang diperoleh siswa pada tes hasil belajar adalah 81,21 dari skor ideal 100 dengan standar deviasi 8,51; (2); banyaknya siswa yang tuntas belajar adalah 25 dari 27 orang (92,59\%); (3) aktivitas siswa dalam proses pembelajaran memenuhi kriteria waktu yang ditetapkan; (4) tanggapan siswa terhadap lembar kegiatan siswa dengan metode penemuan terbimbing sangat positif (5) guru mampu mengelolah pembelajaran dengan menggunakan metode penemuan terbimbing dengan skala penilaian sangat baik.

Kata Kunci: Research and Development, metode penemuan terbimbing, model ADDIE.
\end{abstract}

\begin{abstract}
This research is a research and development research with limited trial which aim to develop activity sheet of mathematics student based on guided discovery method. The subjects of this study were the students of class XII IPS 3 SMA Negeri 1 Segeri with a total of 27 students. The development procedure used in this research is the ADDIE model which includes five stages, namely the analysis phase, the design stage, the development stage, and the implementation and evaluation stage. The Student Activity Sheet developed under the guided discovery method is validated and undergone several revisions to obtain appropriate results for use. The results from the limited trial show that (1) the average score obtained by the students on the learning result test is 81.21 from the ideal score of 100 with the standard deviation of 8.51; (2); the number of students who complete the study is 25 of 27 people (92.59\%); (3) the student activity in the learning process meets the specified time criteria; (4) students' responses to students activity sheets with guided discovery method is very positive (5) teachers are able to manage learning by using guided discovery method with very good rating scale.

Keyword: Research and Development, discovery learning method, ADDIE model.
\end{abstract}




\section{Pendahuluan}

Dalam pendidikan salah satu usaha untuk memperbaiki kehidupan suatu bangsa, harus dimulai dari aspek tujuan, sarana, pembelajaran dan aspek lain yang secara langsung berpengaruh terhadap kualitas pendidikan. Dari berbagai aspek dalam pendidikan, aspek pembelajaran merupakan elemen yang memiliki pengaruh sangat signifikan untuk mewujudkan kualitas lulusan ataupun output pendidikan. Beberapa unsur yang dimaksud adalah guru, peserta didik, bahan ajar dan metode pembelajaran yang diterapkan guru. Jika guru suatu mata pembelajaran seperti pembelajaran matematika pandai dalam memilih bahan ajar, serta menentukan metode pembelajaran yang sesuai untuk diterapkan pada proses pembelajaran, khususnya pada pembelajaran matematika maka tidak mustahil bila peserta didik mampu dalam menguasai atau memahami pelajaran yang diajarkan. Masalah ini tentu menunjukkan masih perlunya peningkatan keterampilan guru dalam mengolah pembelajaran matematika.

Sebenarnya memang tidak begitu mudah bagi seorang guru dalam mengajar ataupun mengolah pelajaran terutama pembelajaran seperti matematika, yang tingkat kerumitannya cukup tinggi, karena pada dasarnya pembelajaran ini lebih membutuhkan banyak latihan dalam mengerjakan soal, dibandingkan dengan pelajaran lain, walaupun pembelajaran matematika sudah diperkenalkan sejak SD hingga Perguruan Tinggi namun tetap saja pelajaran ini belum mampu dalam memberikan rasa tertarik bagi peserta didik untuk mempelajarinya terutama di tingkat Sekolah Menengah Atas.

Di SMA masih menunjukkan lemahnya nilai hasil belajar peserta didik, sehingga belum nampak adanya rasa tertarik terhadap pembelajaran matematika, oleh karena itu perlu adanya suatu pengembangan baik pengembangan metode pembelajaran, dan bahan ajar yang mampu memberikan dampak positif bagi guru, peserta didik, maupun sekolah. Pengembangan bahan ajar cetak yang dimaksud dalam hal ini adalah pengembangan LKS, karena LKS merupakan suatu bahan ajar yang di dalamnya berisi soal latihan, contoh soal, petunjuk cara menyelesaikan soal, beserta materi sehingga mampu melatih dan membimbing peserta didik dalam belajar.

Dari latar belakang inilah penulis perlukan mengadakan penelitian di SMA Negeri 1 Segeri yang didalamnya meneliti tentang Pengembangan lembar kegiatan siswa (LKS) berbasis metode penemuan terbimbing untuk pembelajaran matematika pada siswa kelas XII SMA Negeri 1 Segeri.

Penelitian dan pengembangan Research and Development merupakan metode untuk mengembangkan dan menguji suatu 
produk (Nana Syaodih Sukmadinata, 2010:57). Metode ini banyak digunakan di dunia industri untuk penelitian, mengevaluasi dan menyempurnakan produk-produk lama, dan atau mengembangkan produk baru.

Menurut Endang Mulyatiningsih dalam bukunya Metode Penelitian Terapan Bidang Pendidikan menyatakan bahwa penelitian dan pengembangan bertujuan untuk menghasilkan produk baru melalui proses pengembangan (2013:161), menurut Conny. R. Semiawan penelitian dan pengembangan merupakan perbatasan dari pendekatan kualitatif kuantitatif dan terutama dimaksudkan menjembatani penelitian dan praktik pendidikan (2007:181).

ADDIE merupakan singkatan dari Analysis, Design, Development, or Production or Delivery and Evaluations (Endang Mulyatingsih, 2011:199). Menurut lagkah-langkah pengembangan produk, model penelitian dan pengembangan ini lebih rasional dan lebih lengkap dari pada model 4D. Model ADDIE dikembangkan oleh Dick and Carry untuk merancang sistem pembelajaran. Berikut ini diberikan contoh kegiatan pada setiap tahap pengembangan model atau metode pembelajaran (Endang Mulyatingsih, 2011:200), yaitu: (a) analysis, (b) design, (c) development, (d) implementation, dan (e) evaluation.

Menurut Dewi Puspita Sari, Isriani Hardini (2012:159) Matematika merupakan ilmu universal yang mendasari perkembangan teknologi modern, mempunyai peran penting dalam berbagai disiplin dan memajukan daya pikir manusia.

Pembelajaran matematika menurut Gatot Muhsetyo, dkk (2012:1.26) adalah proses pemberian pengalaman belajar kepada peserta didik melalui serangkaian kegiatan yang terencana sehingga peserta didik memperoleh kompetensi tentang bahan matematika yang dipelajari.

Menurut Gatot Muhsetyo, dkk (2012:1.35) Penemuan Terbimbing adalah suatu kegiatan pembelajaran yang mana guru membimbing siswa-siswanya dengan menggunakan langkah-langkah yang sistematis sehingga mereka merasa menemukan sesuatu.

B. Suryosubroto (2009:178) metode penemuan adalah suatu metode dimana dalam proses belajar mengajar guru memperkenankan siswa-siswanya menemukan sendiri informasi yang secara tradisional biasa diberitahukan atau diceramahkan saja. Inkuiri artinya proses pembelajaran didasarkan pada pencarian dan penemuan melalui proses berfikir secara sistematis (Jumanta Hamdayama, 2014:31).

Dari berbagai pendapat dapat disimpulkan bahwa penemuan terbimbing adalah suatu metode/model/teknik pembelajaran yang mengarahkan siswa menemukan pengetahuan yang mereka anggap suatu pengetahuan baru guna menambah wawasan mereka terhadap suatu pembelajaran melalui proses belajar mengajar yang dipanduh oleh guru, namun pada hakekatnya guru hanya 
berupaya untuk membimbing siswa saja dalam belajar.

Lembar kegiatan siswa adalah panduan siswa yang digunakan untuk melakukan kegiatan penyelidikan atau pemecahan masalah. Lembar kegiatan siswa dapat berupa panduan untuk latihan pengembangan kognitif maupun panduan untuk pengembangan semua aspek pembelajaran dalam bentuk panduan eksperimen atau demonstrasi (Trianto, 2012:222).

Menurut Aris Dwi Cahyono, Daryanto (2014:175) Lembar kegiatan siswa (student worksheet) adalah lembaran-lembaran yang berisi tugas yang harus dikerjakan oleh siswa, lembar kegiatan berisi petunjuk, langkah-langkah untuk menyelesaikan suatu tugas, tugas-tugas yang diberikan kepada siswa dapat berupa teori dan atau peraktik, selain itu dalam pembuatan LKS guru harus melakukan analisis kurikulum ; SK, KD, indikator dan materi pembelajaran. Menyusun peta kebutuhan LKS, menentukan judul LKS, menulis LKS, dan menentukan alat penilaian.

\section{Metode}

Jenis penelitian ini adalah pengembangan dengan model ADDIE (Analysis, Design. Development, Implementation and Evaluation). Subjek dalam penelitian ini adalah kelas XII IPS3 SMA Negeri 1 Segeri.
Tahap-tahap penelitian dan pengembangan model ADDIE (Analysis, Design, Development, Implementation, and Evaluation) akan diuraikan sebagai berikut: 1) Analysis (Tahap Analisis) yaitu (Analisis Kurikulum, Analisis Konsep, Analisis Tugas, Spesifikasi Tujuan Pembelajaran); 2) Design (Tahap Desain); 3) Development (Tahap Pengembangan); 4) Implementation (Tahap Implementasi); dan 5) Evaluation (Tahap Evaluasi).

Instrumen-instrumen dalam penelitian ini adalah: (1) lembar validasi LKS, (2) lembar observasi, (3) angket respon siswa, dan (4) tes penguasaan siswa terhadap materi pelajaran.

Untuk mengumpulkan data dalam penelitian ini dilakukan dengan cara sebagai berikut: (1) data hasil validasi ahli, (2) data pengelolaan pembelajaran, (3) data aktifitas siswa, (4) data dan (5) data hasil belajar siswa.

Data yang telah dikumpulkan dengan menggunakan instrument, selanjutnya dianalisis secara kuantitatif untuk menentukan kevalidan, kepraktisan dan keefektifan. Data yang diperoleh dari hasil validasi oleh para ahli dianalisis untuk menjelaskan kevalidan dan kelayakan penggunaan LKS yang telah dibuat. Adapun data hasil ujicoba di kelas digunakan untuk menjelaskan kepraktisan dan keefektifan. 
Berikut ini dikemukakan tentang analisis data kevalidan, kepraktisan dan keefektifan.

\section{Analisis Data Kevalidan LKS}

Analisis uji kevalidan secara rasional diperoleh melalui hasil validasi para ahli terhadap LKS yang kemudian dianalisis dengan mempertimbangkan penilaian, masukan, komentar dan saran-saran dari validator. Hasil analisis tersebut dijadikan sebagai pedoman untuk merevisi produk yang masih mendapat penilaian kurang.

Koefisien validitas isi dapat dihitung dengan menggunakan rumus berikut :

$$
\text { Validitas isi }=\frac{D}{A+B+C+D}
$$

Tabel 1.

\begin{tabular}{lcc}
\multicolumn{3}{c}{ Validitas isi dari dua validator } \\
\hline Validator 1 & $\begin{array}{c}\text { Tidak relevan } \\
\text { Skor (1-2) }\end{array}$ & $\begin{array}{c}\text { Relevan } \\
\text { Skor (3-4) }\end{array}$ \\
\hline Validator 2 & A & B \\
\hline $\begin{array}{l}\text { Tidak relevan } \\
\text { Skor (1-2) }\end{array}$ & C & D \\
\hline $\begin{array}{l}\text { Relevan } \\
\text { Skor (3-4) }\end{array}$ & & \\
\hline
\end{tabular}

(Rahmat Kamaruddin, 2012:83)

Jika hasil dari koefisian validitas isi ini tinggi ( $\mathrm{V}>75 \%$ ), maka dapat dinyatakan bahwa hasil pengukuran atau interfensi yang dilakukan adalah sahih.

\section{Analisis Data Kepraktisan LKS}

Data hasil pengamatan pengelolaan pembelajaran selama proses pembelajaran dilaksanakan, dianalisis dan dideskripsikan. Instrumen ini dikatakan reliabel jika nilai $R \geq 75 \%$. Koefisien reliabel dihitung berdasarkan kecocokan data hasil pengamatan dari dua pengamat tersebut dan dihitung dengan menggunakan rumus berikut:
Percentage of agreement (R) = $\frac{\text { Agreements }}{\text { Disagreements+agreement }} \times 100 \%$

(Sumber: Subhan, 2016:50)

Sebagai kriteria kemampuan guru mengelola pembelajaran dikatakan "memadai" apabila konversi nilai rata-rata setiap aspek pengamatan diberikan oleh dua orang pengamat pada setiap pertemuan berada pada kategori baik atau sangat baik, apabila TKG (Tingkat Kemampuan Guru) di dalam kategori lainnya, maka guru harus meningkatkan kemampuan dengan memperhatikan aspek-aspek yang dinilainya kurang.

$0,0 \leq$ TKG $<0,5$ berarti tidak baik

$0,5 \leq$ TKG $<1,5$ berarti kurang baik

$1,5 \leq$ TKG $<2,5$ cukup baik

$2,5 \leq \mathrm{TKG}<3,5$ berarti baik

$3,5 \leq$ TKG $\leq 4,0$ berarti sangat baik

(Sumber: Subhan, 2016:51)

\section{Analisis Data Keefektifan LKS}

Analisis terhadap keefektifan LKS didukung oleh hasil analisis data dari beberapa komponen keefektifan, yaitu (1) hasil belajar siswa atau ketuntasan klasikal, (2) aktivitas siswa, (3) respons siswa. Oleh karena itu, kegiatan analisis data terhadap keempat komponen itu adalah sebagai berikut:

Analisis Data Hasil Belajar Siswa

Kemampuan siswa dapat dikelompokkan dalam skala lima beradasarkan teknik kategorisasi standar yaitu sebagai berikut:

1. Kemampuan $85 \%-100 \%$ atau skor 85 - 100 dikategorikan sangat tinggi 
2. Kemampuan $65 \%$ - $84 \%$ atau skor 65 - 84 dikategorikan tinggi

3. Kemampuan $55 \%$ - $64 \%$ atau skor 55 - 64 dikategorikan sedang

4. Kemampuan $35 \%$ - $54 \%$ atau skor 35 - 54 dikategorikan rendah

5. Kemampuan $0 \%-34 \%$ atau skor 0 - 34 dikategorikan sangat rendah

(Sumber: Subhan, 2016:45)

Pada pembelajaran matematika, Kriteria Ketuntasan Minimal (KKM) yang harus dipenuhi oleh seorang siswa adalah 70. Jika seorang siswa memperoleh skor 70 atau di atas 70 maka siswa yang bersangkutan mencapai ketuntasan individu. Jika minimal 85\% siswa mencapai skor minimal 70, maka ketuntasan klasikal telah tercapai (KKM ditentukan oleh sekolah bersangkutan).

a. Analisis Data Aktivitas Siswa

Data hasil pengamatan aktivitas siswa selama kerjasama dalam kelompok dilaksanakan, dianalisis dan dideskripsikan. Untuk mencari persentase aktivitas siswa dan waktu yang digunakan, dianalisis sebagai berikut:

$$
P T a=\frac{\sum T a}{\sum T} X 100 \%
$$

(Sumber: Subhan, 2016:46)

Keterangan:

PTa = Persentase aktivitas siswa untuk melakukan suatu jenis aktivitas tertentu.

$\mathrm{Ta}=$ Jumlah jenis aktivitas siswa yg dilakukan setiap pertemuan $\Sigma \mathrm{T}=$ Jumlah seluruh aktivitas siswa.
Kemudian persentase aktivitas siswa tersebut dibandingkan dengan rentang baik yang diperoleh dari persentase waktu ideal dengan menggunakan toleransi $5 \%$. Persentase waktu ideal siswa dalam melakukan aktivitas tertentu dihitung berdasarkan persentase jumlah alokasi waktu dari seluruh RPP pada aktivitas tertentu terhadap jumlah waktu seluruh RPP yang rumusnya sebagai berikut.

$$
P w i=\frac{\sum w a}{\sum w} X 100 \%
$$

(Sumber: Subhan, 2016:46)

Pwi : Persentase waktu ideal untuk melakukan suatu jenis aktivitas tertentu ¿wa : Jumlah alokasi waktu dari semua RPP pada aktivitas tertentu.

$\Sigma \mathrm{w}$ : Jumlah seluruh alokasi waktu.

b. Analisis Respon Siswa

Kriteria yang ditetapkan untuk menyatakan bahwa para siswa memiliki respon positif terhadap LKS dengan penerapan metode penemuan terbimbing adalah jika 50\% dari mereka memberi respon positif terhadap minimal 70\% jumlah aspek yang ditanyakan. Maka respon positif siswa untuk aspek LKS terpenuhi. (Sumber: Subhan, 2016:49).

\section{Hasil dan Pembahasan}

\section{A. Hasil Pengembangan Perangkat pembelajaran}

Singkatan yang sudah umum seperti seperti IPA, IPS, RPP, dan LKS tidak perlu 
diberi keterangan kepanjangannya. Akan tetapi, akronim yang tidak terlalu dikenal atau akronim bikinan penulis perlu diberi keterangan kepanjangannya. Sebagai contoh: "Pendekatan RME (Realistic Mathematics Education) dapat digunakan untuk memberikan pembelajaran yang diawali dengan suatu konteks". Jangan gunakan singkatan atau akronim pada judul artikel, kecuali tidak bisa dihindari.

Telah diuraikan pada Bab I bahwa tujuan penelitian ini adalah untuk menghasilkan LKS berbasis metode penemuan terbimbing pada siswa kelas XII SMA Negeri 1 Segeri yang valid, praktis, dan efektif. Prosedur pengembangan perangkat pembelajaran yang digunakan adalah model pengembangan ADDIE (Analysis, Design, Development, Implementation, Evaluation) dengan urutan tahapan pengembangan adalah tahap analisis (analysis), tahap desain (design), tahap pengembangan (development), tahap imlementasi (implentation) dan tahap evaluasi (evaluation). Hasil pengembangan perangkat pembelajaran diuraikan sebagai berikut.

1. Hasil Tahap Analisis (Analysis), yaitu: Analisis Kurikulum, Analisis Siswa, Analisis Konsep, Analisis Tugas, dan Spesifikasi Tujuan Pembelajaran.

2. Tahap Analisis Pembelajaran (Design), yaitu: Penyusunan Kerangka LKS, Pemilihan Format, dan Rancangan Awal.
3. Tahap Pengembangan (Develop), yaitu: Penafsiran Ahli.

4. Analisis Kevalidan LK. Analisis kevalidan LKS dapat dilihat dari analisis dan revisi terhadap rencana perangkat pembelajaran oleh para ahli yang diperoleh berdasarkan penilaian para ahli.

\section{B. Hasil Penilaian Ahli terhadap RPP}

(1) Nilai rata-rata kevalidan aspek kompetensi dasar diperoleh adalah $\bar{x}=4$ dapat disimpulkan bahwa nilai ini termasuk dalam kategori "Sangat Valid" $(3,5 \leq \bar{x} \leq 4)$.

(2) Nilai rata-rata kevalidan aspek indikator pencapaian kompetensi dasar adalah $\bar{x}=4$ dapat dikatakan bahwa nilai ini termasuk dalam kategori "Sangat Valid" $(3,5 \leq \bar{x} \leq$ 4).

(3) Nilai rata-rata kevalidan aspek isi dan kegiatan pembelajaran adalah $\bar{x}=4$ dapat dikatakan bahwa nilai ini termasuk dalam kategori "Sangat Valid" $(3,5 \leq \bar{x} \leq 4)$.

(4) Nilai rata-rata kevalidan aspek bahasa adalah $\bar{x}=4$ dapat dikatakan bahwa nilai ini termasuk dalam kategori "Sangat Valid" $(3,5 \leq$ $\bar{x} \leq 4)$.

(5) Nilai rata-rata kevalidan waktu adalah $\bar{x}=4$ dapat dikatakan bahwa nilai ini termasuk dalam kategori "Sangat Valid" $(3,5 \leq \bar{x} \leq$ 4). Jadi ditinjau dari aspek kompetensi dasar RPP ini dinyatakan memenuhi kriteria kevalidan 
(6) Nilai rata-rata kevalidan aspek penutup adalah $\bar{x}=4$ dapat dikatakan bahwa nilai ini termasuk dalam kategori "Sangat Valid" $(3,5 \leq$ $\bar{x} \leq 4)$.

\section{Hasil penilaian terhadap Lembar Kegiatan siswa (LKS) oleh para ahli}

(1) Nilai rata-rata total kevalidan LKS adalah $\bar{x}=4$, dapat dikatakan bahwa nilai ini termasuk dalam kategori "Sangat Valid" $(3,5 \leq \bar{x} \leq$ 4).

(2) Nilai rata-rata kevalidan aspek format LKS adalah $\bar{x}=4$ dapat dikatakan bahwa nilai ini termasuk dalam kategori "Sangat Valid" (3,5 $\leq \bar{x} \leq 4)$.

(3) Nilai rata-rata kevalidan aspek bahasa adalah $\bar{x}=4$ dapat dikatakan bahwa nilai ini termasuk dalam kategori "Sangat Valid" $(3,5 \leq$ $\bar{x} \leq 4)$.

(4) Nilai rata-rata kevalidan aspek isi LKS adalah $\bar{x}=4$, dapat dikatakan bahwa nilai ini termasuk dalam kategori "Sangat Valid" $(3,5 \leq \bar{x} \leq 4)$.

D. Hasil Penilaian terhadap Tes Hasil Belajar (THB) oleh Para Ahli

(1) Nilai rata-rata total kevalidan Tes Hasil Belajar (THB) adalah $\bar{x}=4$ dapat dikatakan bahwa nilai ini termasuk dalam kategori "Sangat Valid" $(3,5 \leq \bar{x} \leq 4)$. Jadi ditinjau dari keseluruhan aspek, Tes Hasil Belajar (THB) ini dinyatakan memenuhi kriteria kevalidan

(2) Nilai rata-rata kevalidan Tes Hasil Belajar (THB) dari aspek isi adalah $\bar{x}=4$ dapat dikatakan bahwa nilai ini termasuk dalam kategori "Sangat Valid" $(3,5 \leq \bar{x} \leq 4)$. Jadi ditinjau dari aspek isi, Tes Hasil Belajar (THB) ini dinyatakan memenuhi kriteria kevalidan.

(3) Nilai rata-rata kevalidan Tes Hasil Belajar (THB) dari aspek bahasa adalah $\bar{x}=4$ dapat dikatakan bahwa nilai ini termasuk dalam kategori "Sangat Valid" $(3,5 \leq \bar{x} \leq 4)$. Jadi ditinjau dari aspek bahasa, Tes Hasil Belajar (THB) ini dinyatakan memenuhi kriteria kevalidan.

Tabel 2.

Rangkuman Hasil Validasi Perangkat Pembelajaran

Perangkat Skor Rata- Kriteria Rata Penilaian

\begin{tabular}{lll}
\hline RPP & 4 & Sangat Valid \\
\hline LKS & $\mathbf{4}$ & Sangat Valid \\
\hline Tes Hasil Belajar & 4 & Sangat Valid \\
Keterangan : & & \\
- & Sangat Valid (SV) & $: 3.5 \leq \mathrm{M} \leq 4$ \\
$\bullet$ & Valid (V) & $: 2,5 \leq \mathrm{M}<3,5$ \\
$\bullet$ & Cukup Valid (CV) & $: 1,5 \leq \mathrm{M}<2,5$ \\
$\bullet$ & Tidak Valid (TV) & $: \mathrm{M}<1,5$
\end{tabular}

Dapat disimpulkan bahwa perangkatperangkat yang disebutkan pada tabel tersebut sudah temasuk dalam kategori "sangat valid" $(3,5 \leq \bar{x} \leq 4)$. Berdasarkan 
kriteria kevalidan yang telah dibahas pada bab III, maka perangkat pembelajaran telah memiliki derajat validitas yang memadai dan layak untuk diujicobakan. Namun perangkat-perangkat tersebut menurut saran para ahli masih perlu diperbaiki/ditambah.

\section{E. Implementasi/ (Implementation)}

Pelaksanaan

Sebagaimana yang telah disebutkan sebelumnya bahwa perangkat pembelajaran hasil revisi berdasarkan masukan atau saran dari validator yang selanjutnya dilaksanakan atau diterapkan pada siswa kelas XII IPS3 SMAN 1 Segeri.

\section{F. Tahap Evaluasi (Evaluation)}

a. Hasil evaluasi LKS

Dari hasil evaluasi LKS, diperoleh nilai rata-rata minimum dan maksimum yang diperoleh siswa masing-masing adalah berkisar 87 dan 98,6. Evaluasi terhadap pengembangan LKS untuk penilian keefektifan dan kepraktisan LKS dapat diperoleh dari hasil analisis berikut ini.

b. Analisis Keefektifan Lembar Kerja Siswa (LKS)

1) Hasil Tes Belajar Siswa

Hasil analisis deskriptif secara kuantitatif penguasaan matematika setelah tindakan pada tes hasil belajar diperoleh skor rata-rata 81,21 dari skor ideal 100 dengan standar deviasi 8,51. Skor minimum yang diperoleh siswa adalah 62,65 dan skor maksimum yang diperoleh siswa adalah 93,97 dengan rentang skor 83.00 .
Selain itu, banyaknya siswa yang tuntas belajar atau mencapai ketuntasan individu yaitu siswa yang memperoleh skor nilai 70 ke atas sebanyak 25 orang dari 27 siswa atau sekitar 92,59\%. Jadi banyaknya siswa yang belum tuntas yaitu siswa yang memperoleh nilai di bawah 70 , sebanyak 2 orang atau sekitar 7,41\%.

2) Analisis Hasil Pengamatan Aktivitas Siswa

Pembagian kelompok didasarkan pada nilai matematika semester lalu dan hasil masukan setelah melakukan diskusi dengan guru mata pelajaran matematika yang menangani kelas tersebut.

Tabel 3.

Rata-Rata Persentase Waktu Aktivitas Siswa

\begin{tabular}{|c|c|c|c|c|c|}
\hline \multirow{2}{*}{$\begin{array}{c}\text { Kategor } \\
\text { i }\end{array}$} & \multicolumn{3}{|c|}{ Pertemuan } & \multirow{2}{*}{$\begin{array}{c}\text { Rata- } \\
\text { rata (\%) }\end{array}$} & \multirow{2}{*}{$\begin{array}{c}\text { Interval } \\
\text { Toleran } \\
\text { si (\%) }\end{array}$} \\
\hline & 1 & II & III & & \\
\hline 1 & 5,6 & 5,56 & 5,6 & 5,56 & $0-5$ \\
\hline 2 & 5,6 & 5,56 & 5,6 & 5,56 & $0-5$ \\
\hline 3 & 22 & 15,3 & 21 & 19,2 & $\begin{array}{l}17,2- \\
27,2\end{array}$ \\
\hline 4 & 11 & 11,1 & 10 & 10,9 & $\begin{array}{l}6,1- \\
16,1\end{array}$ \\
\hline 5 & 5,6 & 5,56 & 5,6 & 5,56 & $0-5$ \\
\hline 6 & 26 & 25,7 & 27 & 26,4 & $\begin{array}{l}17,2- \\
27,2\end{array}$ \\
\hline 7 & 16 & 16 & 16 & 16 & $\begin{array}{l}11,6- \\
21,6\end{array}$ \\
\hline 8 & 4,9 & 5,56 & 5,6 & 5,32 & $0-5$ \\
\hline 9 & 3,5 & 9,72 & 3,5 & 5,56 & $\begin{array}{l}6,1- \\
16,1\end{array}$ \\
\hline
\end{tabular}

\section{G. Respon Siswa Terhadap Lembar Kegiatan Siswa}

Sesuai hasil persentase dari 15 item pernyataan di atas dengan kriteria yang telah ditetapkan pada Bab III, maka aspek respons dari segi bahasa yaitu $84.44 \%$ sedangkan aspek dari segi isi yaitu $84,81 \%$, 
maka respon siswa terhadap lembar kegiatan siswa secara kesluruhan yaitu $84,62 \%$

Berdasarkan data analisis respon siswa terhadap lembar kegiatan siswa jika dihubungkan dengan kriteria respon siswa terhadap keseluruhan komponen pembelajaran matematika materi matriks dengan metode penemuan terbimbing adalah "positif".

\section{H. Pembahasan}

Pada bagian ini dikemukakan pembahasan tentang hasil penelitian yang telah diperoleh, meliputi tiga hal, yaitu: (1) ketercapaian tujuan penelitian, dan (2) kendala-kendala yang ditemui.

Pada bagian ketercapaian tujuan penelitian yang akan diuraikan adalah seberapa jauh penelitian yang direncanakan tercapai. Ketercapaian ini dikaitkan dengan kevalidan, kepraktisan, dan kefektifan lembar kegiatan siswa dengan metode penemuan terbimbing.

Temuan khusus yang dimaksud dalam bagian pembahasan ini adalah temuantemuan yang diperoleh peneliti selama pelaksanaan uji coba lembar kegiatan siswa dengan metode penemuan terbimbing, khususnya yang terkait langsung dengan siswa XII IPS3 SMA Negeri 1 Segeri sebagai subjek penelitian.

\section{Penutup}

Berdasarkan hasil penelitian yang telah diuraikan pada bab IV, maka dapat disimpulkan bahwa hasil uji coba LKS yang dikembangkan dengan berbasis metode penemuan terbimbing untuk pembelajaran matematika pada siswa kelas XII SMA Negeri 1 Segeri telah dinyatakan temasuk dalam kategori LKS yang valid, praktis dan efektif.

\section{DAFTAR PUStaka}

Ali Hamzah, 2014, Evaluasi Pembelajaran Matematika, Raja Grafindo Persada, Jakarta

Aris Dwi Cahyono, Daryanto, 2014, Pengembangan Perangkat Pembelajaran (Silabus, RPP, PHB, Bahan Ajar), Yogyakarta Gava Media, Yogyakarta

Conny R. Semiawan, 2007, Catatan Kecil Tentang Penelitian Dan Pengembangan IImu Pengetahuan, Kencana Predana Media Grup, Jakarta Dany Haryanto, Niken Ariani, 2010, Pembelajaran Multimedia di Sekolah Pedoman Pembelajaran Inspiratif, Konstruktif, dan Prospektif, Prestasi Pustaka Publisher, Jakarta

Dewi Puspita Sari, Isriani Hardini, 2012, Sarategi Pembalajaran Terppadu (Teori, konsep \& Implementasi), Rosdakarya, Pekalongan

Endang Mulyatiningsih, 2011, Metode Penelitian Terapan Bidang Pendidika, Alfabeta, Bandung 
Jumanta Hamdayama, 2014, Model dan Metode pembelajaran Kreatif Dan Berkarakter, Ghalia Indonesia, Jakarta

Masnur Muslich, 2009, KTSP Pembelajaran Berbasis Kompetnsi dan Kontekstual, Bumi Aksara, Malang

Nana Syaodih Sukmadinata, 2010, Metode Penelitian Pendidikan, Remaja Rosdakarya, Bandung

Rahmad Kamaruddin, 2012, Pengembangan Bahan Ajar Materi Geometri Berdasarkan Teori Belajar Van Hiele Berbasis karakter untuk Siswa Kelas VII SMP, Tesis, PPs UNM, Makassar

Risma, 2015, Penerapan Model Discovery Learning Terhadap Hasil Belajar Matematika pada Siswa Kelas VIII SMP Negeri 3 Labakkang, Skripsi, STKIP Andi Matappa, Pangkep

Roestyah N.K, 2001, Strategi Belajar Mengajar, Rineka Cipta, Jakarta

\section{Riwayat Hidup PENULIS}

Zam Immawan Alam, S.H. M.H.

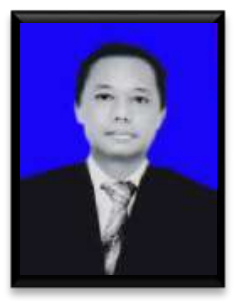

Lahir di Ujung Pandang, 7 April 1970. Ketua di STKIP Andi Matappa Pangkep. Studi: S1 Ilmu Hukum di Universitas Muslim Indonesia, Makassar tahun 1990 dan lulus tahun 1994; S2 Ilmu Hukum di Universitas Indonesia Timur, Makassar pada tahun 2010 dan lulus tahun 2012. Tahun 2017 menjadi pembicara/penyaji makalah dalam pertemuan ilmiah Seminar Internasional " $2^{\text {nd }}$ ICSMTR 2017".

Firdha Razak, S.Pd. M.Pd.

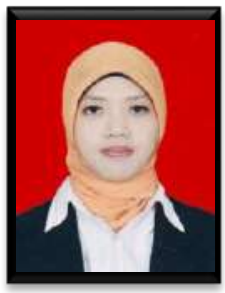

Lahir di Pangkajene, 22 Mei 1989. Staf pengajar di STKIP Andi Matappa Pangkep. Studi : S1 Pendidikan Matematika di STKIP Andi Matappa, Pangkep tahun 2007 dan lulus tahun 2011; S2 Pendidikan Matematika di Universitas Negeri Makassar pada tahun 2012 dan lulus tahun 2014. Tahun 2017 mendapat Hibah Penelitian Dosen Pemula dari Ristekdikti dengan Judul "Analisis Tingkat Berpikir Siswa Berdasarkan Teori Van Hiele pada Materi Pokok Dimensi Tiga Ditinjau dari Gaya Kognitif Kelas XII SMA Negeri 1 Pangkajene". Tahun 2017 menjadi pembicara/penyaji makalah dalam pertemuan IImiah Seminar Nasional Universitas Cokroaminoto Palopo dan pertemuan ilmiah Seminar Internasional " 2 nd ICSMTR 2017" 
This page is intentionally left blank 